Article

\title{
Concentrations of Available Heavy Metals in Mediterranean Agricultural Soils and their Relation with Some Soil Selected Properties: A Case Study in Typical Mediterranean Soils
}

\section{José Rato Nunes ${ }^{1,2, *}$, José Ramos-Miras ${ }^{3, \dagger}$, António Lopez-Piñeiro ${ }^{4, \dagger}$, Luís Loures ${ }^{2,5, \dagger}$,} Carlos Gil ${ }^{3, \dagger}$, José Coelho ${ }^{6, \dagger}$ and Ana Loures ${ }^{2}$

1 Unidade de Investigação em Química Ambiental (UIQA), Instituto Superior de Agronomia, Universidade de Lisboa, Tapada da Ajuda, Lisboa 1340-017, Portugal

2 Instituto Politécnico de Portalegre, Praça do Municipio, Portalegre 7300, Portugal;

E-Mails: 1cloures@esaelvas.pt (L.L.); alloures@esaelvas.pt (A.L.)

3 Escuela Politécnica Superior, Departamento de Agromia, Área de Química Agrícola, Universidad de Almería, Almeria 04120, Spain; E-Mails: nashorn_16@hotmail.com (J.R.-M.); cgil@ual.es (C.G.)

4 Department of Edaphology, Universidad da Extremadura, Badajoz 06071, Spain;

E-Mail: pineiro@unex.es

5 Centre for Spatial and Organizational Dynamics (CIEO), Universidade do Algarve, Faro 8005-139, Portugal

6 Instituto Superior de Agronomia, Universidade de Lisboa, Tapada da Ajuda, Lisboa 1340-017, Portugal; E-Mail: josecoelho@isa.ulisboa.pt

$\dagger$ These authors contributed equally to this work.

* Author to whom correspondence should be addressed; E-Mail: ratonunes@esaelvas.pt; Tel.: +351-26-8628-528.

External Editor: Marc A. Rosen

Received: 16 October 2014; in revised form: 25 November 2014 / Accepted: 27 November 2014 / Published: 9 December 2014

\begin{abstract}
The characterization of the content of trace metals in soils is an instrument in many programs of environmental protection, including the establishment of regional-level standards to detect sites affected by contamination. The objectives of the present study were to study the available levels of $\mathrm{Cd}, \mathrm{Cr}, \mathrm{Cu}, \mathrm{Ni}, \mathrm{Pb}$, and $\mathrm{Zn}$ in surface horizons of agricultural soils in a typical European Mediterranean region, to establish the geochemical
\end{abstract}


baseline concentration (GBC), background level (BL), and reference value (RV) of each of these available metals, and to investigate their possible correlations with soil properties. To establish the GBC and RV values, we used the "standard threshold method". Topsoil samples $(0-20 \mathrm{~cm})$ were collected from 630 sites, and extracted with Diethylene Triamine Pentaacetic Acid (DTPA) to determine their available heavy metal concentrations. The GBC values established were: 0.04 to $0.90 \mathrm{mg} \mathrm{kg}^{-1}, 0.70$ to $2.50 \mathrm{mg} \mathrm{kg}^{-1}, 0.10$ to $6.30 \mathrm{mg} \mathrm{kg}^{-1}, 0.30$ to $7.90 \mathrm{mg} \mathrm{kg}^{-1}, 0.29$ to $4.50 \mathrm{mg} \mathrm{kg}^{-1}$, and 0.18 to $2.50 \mathrm{mg} \mathrm{kg}^{-1}$ for $\mathrm{Cd}$, $\mathrm{Cr}, \mathrm{Cu}, \mathrm{Ni}, \mathrm{Pb}$, and $\mathrm{Zn}$, respectively. Soil properties were found to be correlated with the available heavy metal content, suggesting that the enhanced mobility of heavy metals are related to anthropic activities.

Keywords: available heavy metals; Mediterranean agricultural soils; DTPA; geochemical baseline concentrations; reference values

\section{Introduction}

The Mediterranean region has been subject to intense anthropic pressure for millennia, resulting in a vulnerable and often fragile ecosystem [1]. Livestock and crop farming are the main human activities in the area [2]. The excessive use of fertilizers in the region has, in general, led to soil acidification, problems of soil degradation, and a major proportion of contaminant trace metals [3-6]. Moreover, in the European Mediterranean region, cropping intensity is often inconsistent with the soil's natural potential, with $26 \%$ of the soils used for farming being in fact unsuitable for that purpose [6]. These activities, coupled with other planned and unplanned actions by men have contributed to increase landscape change [7-9] raising global alertness related to the need to rethink the impact of several agricultural practices in order not only to protect the environment, but also to reduce their impact, in which heavy metal concentrations is a major concern.

The concentration of heavy metals in agricultural soils is mainly related with the parental material of the area [10], although there are only few studies on availability and mobility of the heavy metals in agricultural soils.

The characterization of the content and sources of heavy metals in soils is a key element in many programs of environmental protection, including the establishment of regional-level quality standards to detect sites affected by contamination $[11,12]$. The accumulation of heavy metals in the soil is considered to be a serious risk at the environmental level [13]. Published results on the levels of heavy metals in soils been based on indirect estimation, small-scale studies, or poorly defined time periods, but often represent the only information available for extensive territories. Also, they are not only hard to extrapolate, but seem unlikely to provide any reliable picture of long-term trends that might be applicable to any large agricultural area under commercial management. For this reason, the present large-scale field study represents a major research contribution to determining and quantifying the impact of agriculture on soil available heavy metal content under Mediterranean conditions.

It is widely accepted that determining the total content of heavy metals in a soil is neither sufficient to understand their relative mobility and ecological availability as contaminants nor particularly useful 
as a tool to estimate potential risks. The toxicity of metals for plants and animals including humans depends not only on their total concentrations, but also on their mobility and reactivity with other components of the ecosystem [14,15]. The "bioavailable fraction" is the fraction of the total contaminant in the interstitial water and soil particles that is available to the receptor organism [16]. However, there is still very little direct measurement data or predictions of the available fraction of metals in soils. In Portugal and Spain for instance, there is hardly any information at all on available heavy metals in agricultural soils, and this lack of information is reflected in poorly informed legislation, which does not take soil characteristics into account [17,18]. The initial soil $\mathrm{pH}$ and the ability of plant roots to change the $\mathrm{pH}$ have been found to be the principal predictors of the exchange of heavy metals, and therefore of their bioavailability [19]. It is generally accepted that anthropogenic heavy metal contamination exists mainly in the form of reactive species on the soil surface, and the concepts of "bioavailability" and "bio-accessibility" were introduced to express the actual effect of the concentration of a contaminant on organisms in the ecosystem [16,20-22].

Following [23] "The term geochemical baseline indicates the actual content of an element in the superficial environment at a given point in time, as is defined by Salminen and Gregorauskiene (2000) cited by [23]. The geochemical baseline in an area of heavy anthropogenic impact includes the geogenic, natural content (background). The determination of background (geogenic) values, in contrast to baseline values, is very important for defining the extent of pollution in areas where environmental legislation has not yet established intervention limits for all environmental matrices".

The geochemical baseline concentration (GBC) and background level (BL) of different heavy metals in soils have been studied in various Mediterranean countries [12,18,23-28]. It is widely accepted that the BL and GBC were the best approach to establish the levels of non-contaminated soils 26 Different approaches have been taken to establishing the GBC of trace elements in Mediterranean soils [12,18,29-31]. Most have centered on the total heavy metal content without considering the bioavailability of the different elements involved [32], even though, according to Baldantoni et al. [33], bioavailability constitutes the best indicator of the potential impact of these contaminants.

The present study is aimed at contributing to improved information on available heavy metals in Mediterranean agricultural soils in particular, it being important to bear in mind that there is only limited data available on available heavy metals in Mediterranean soils in general. Given this context, the specific objectives were: (i) to study the levels of available heavy metals in typical agricultural soils of a Mediterranean region; (ii) to establish the available GBC of these metals; and (iii) to establish relationships between available heavy metals and certain soil properties.

\section{Experimental Section}

\subsection{Study Area and Sampling}

The study area is located within the administrative townships of Elvas and Campo Maior, at the confluence of the Rivers Caia and Guadiana, near the Portuguese-Spanish border (Figure 1).

The geology of this area consists essentially of Cambrian and Silurian formations, with some small eruptive zones associated with hyper-alkaline and alkaline rocks [34]. The average annual rainfall is 
approximately $483 \mathrm{~mm}$, most of which coincides with the coolest temperatures from October to March. The maximum average monthly temperature corresponds to July with $24.7{ }^{\circ} \mathrm{C}$ and the minimum to January with $8.8^{\circ} \mathrm{C}$. The Mediterranean region is characterized by its hot dry summers (with direct influence in soils properties) and cool wet winters. The most important crops are: maize (Zea mays) for feed-grain production with almost half of the cultivated area (49\%), wheat (Triticum aestivum) (17\%), sunflower (Helianthus annuus) (7\%), tomato (Lycopersicum esculento) (6\%), and olive (Olea europea) (4\%).

Figure 1. Localization map of the area studied.

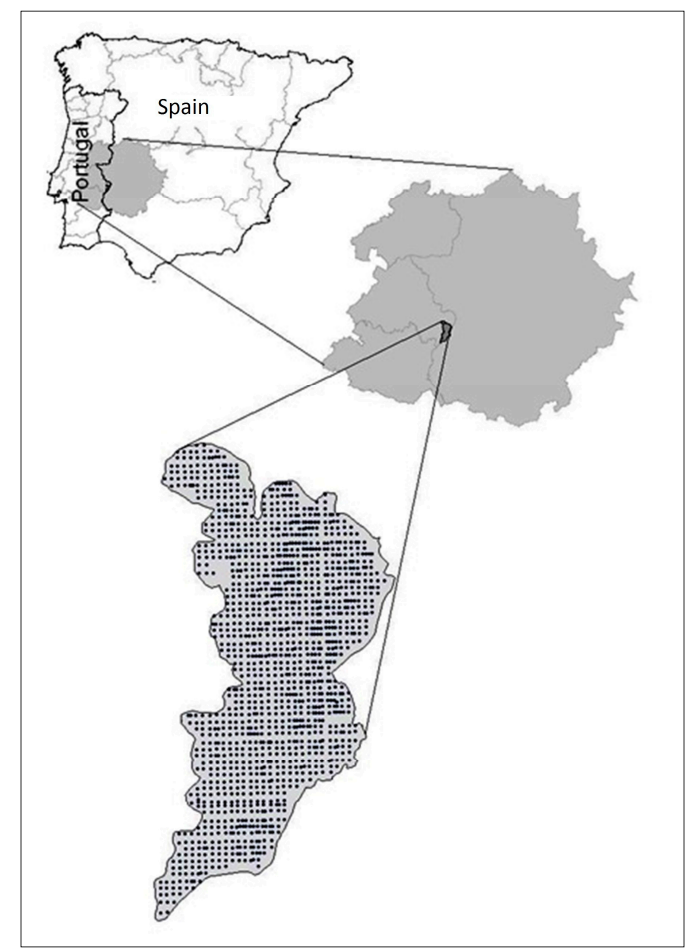

A total of 630 sites were selected in the "Caia Irrigation Perimeter". At each sample site, 10 topsoil $(0-20 \mathrm{~cm})$ subsamples were collected at random and merged to give a composite sample of roughly $2 \mathrm{~kg}$. Later all samples were air dried, crushed and sieved to $<2 \mathrm{~mm}$, and stored.

\subsection{Analytical Methods}

The physical and chemical soil analyses were carried out following Roca-Pérez [35] and Soil Survey Laboratory Methods Manual [36] and were determined for each individual soil (data not show). The available heavy metals were determined by the method described by Lindsay and Norvell [37] (extraction with DTPA $+\mathrm{CaCl}_{2}+$ triethanolamine). According to Hooda and Alloway [38]; Soriano-Disla et al. [39] and Hao et al. [40], DTPA extraction is the most efficient method of extracting heavy metals from soils, independently of the soil's properties, and hence can be an effective way to assess the availability of heavy metals to plants. We considered this fraction as bioavailable heavy metals.

Total heavy metals were determined following the method described in EPA 3052 [18]. The concentrations of $\mathrm{Cd}, \mathrm{Cr}, \mathrm{Cu}, \mathrm{Ni}, \mathrm{Pb}$, and $\mathrm{Zn}$ (total and available) were determined by ICP-OES (IRIS 
INTREPID II XDL THERMO). Measurements were made in triplicate for each sample to check the precision of the results. To assess both the quality of the methods applied and the assay by atomic absorption spectroscopy, a check was made for matrix interferences using standard addition techniques. No such interferences were observed for the determination of the metals studied. In other hand 30 samples were re-analyzed and a paired $t$-test realized, the results indicated no significant differences in the values [41]. The concentrations of available $\mathrm{Cd}, \mathrm{Cr}, \mathrm{Cu}, \mathrm{Ni}, \mathrm{Pb}$, and $\mathrm{Zn}$ are indicated as $\mathrm{mg} \mathrm{kg}^{-1}$ dry matter. The limit of detection of the method was $0.01 \mathrm{mg} \mathrm{kg}^{-1}$ for both, total and available heavy metals

The Zn Equivalent Indices (ZnEqT for total heavy metals and ZnEqB for available heavy metals) were used to compare the potential heavy metal toxicity in these soils $[12,17,18,42]$. They both were calculated as:

$$
\mathrm{ZnEq}=[\mathrm{Zn}]+2[\mathrm{Cu}]+8[\mathrm{Ni}]
$$

where $[\mathrm{Zn}],[\mathrm{Cu}]$, and $[\mathrm{Ni}]$ are the respective soil concentrations of the metal (total and available for $\mathrm{ZnEqT}$ and $\mathrm{ZnEqB}$, respectively).

\subsection{Statistical Analyses}

All statistical analyses were performed using the SPSS version 15.0 software package, calculating the arithmetic mean (AM), range (MINV-MAXV), standard deviation (SD), and geometric mean (GM) as descriptive statistics. The relationships between soil properties and heavy metal concentrations were analyzed using Spearman's correlation coefficient. The significance level taken for Student's $t$-test was $\alpha=0.05$.

\subsection{Baseline Concentrations}

To establish the GBC and BL values, the soil sample population was segregated into non-contaminated and contaminated soils on the basis of probability plots applying the "standard threshold method" described by Fleischhauer and Korte [43] and used by several authors.

Following this method a log-normal distribution was assumed, and Q-Q plots were drawn. From these plots the overlap corresponding to different population can be determined from slope changes of the plots. The tipping points formed by the superposition of the two populations were identified as data endpoints of the raw data for which the resulting population has skewedness nearest to zero, hence the populations can be segregated (contaminated and non-contaminated soils). The reference value (RV) was taken as the upper limit of the GBC, and was used to determine whether a soil might be contaminated or not [41]. The identification of a specific type of soil as contaminated means that the total contaminant content is higher than would normally be expected in non-contaminated areas [31]. The RV values were used to evaluate the soils' contamination and quality.

\section{Results and Discussion}

The main soil characteristics are listed in Table 1. The commonest soil groups in the study area are Fluvisols (42.7\%), Luvisols (21.7\%), Calcisols (16.1\%), Cambisols (6.1\%), Vertisols (1.8\%), and Regosols $(0.6 \%)$, as is usual in Mediterranean ecosystems [34]. In general, these are medium-loam and 
clay-loam soils with a $\mathrm{pH}$ close to 7, slightly calcareous, and low levels of soil organic matter (SOM, $1.54 \%$ ) and total nitrogen (, $0.1 \%$ ). They have intermediate levels of cation exchange capacity (CEC, $15.8 \mathrm{cmolc} \mathrm{kg}^{-1}$ ), with calcium as the principal exchangeable cation, and a degree of saturation of exchangeable cations of $70 \%$. Their levels of available phosphorus and potassium $\left(\mathrm{P}_{2} \mathrm{O}_{5}\right.$ and $\mathrm{K}_{2} \mathrm{O}_{\text {, }}$ respectively) are high, indicating intensive use of soil fertilizers, which is, thus, suggestive that farming may be incorporating pollutants into the soils [44,45]. Their saturated soil-paste electrical conductivity at $25^{\circ} \mathrm{C}$ is low $\left(\mathrm{EC} 25,0.11 \mathrm{dS} \mathrm{m}^{-1}\right)$, indicating that these soils have no salinity problems.

Table 1. Mean values, standard deviation, and ranges for general descriptive parameters of Caia soils $(n=630)$.

\begin{tabular}{ccccccccc}
\hline $\begin{array}{c}\text { Statistical } \\
\text { Parameters }\end{array}$ & $\begin{array}{c}\text { SOM } \\
(\%)\end{array}$ & $\mathbf{N}(\%)$ & $\begin{array}{c}\text { Soil Carbonates } \\
(\mathbf{\%})\end{array}$ & $\mathbf{p H}$ & $\begin{array}{c}\mathbf{C E C} \\
\mathbf{c m o l}_{\mathbf{c}} \mathbf{k g}\end{array}$ & $\begin{array}{c}\mathbf{C E}_{\mathbf{2 5}} \\
\mathbf{d S ~ m}^{-\mathbf{1}}\end{array}$ & $\begin{array}{c}\mathbf{P}_{\mathbf{2}} \mathbf{O}_{\mathbf{5}} \\
(\mathbf{m g} / \mathbf{1 0 0} \mathbf{g})\end{array}$ & $\begin{array}{c}\mathbf{K}_{\mathbf{2}} \mathbf{O} \\
(\mathbf{m g} / \mathbf{1 0 0} \mathbf{g})\end{array}$ \\
\hline MINV & 0.2 & 0.03 & 0.1 & 4.5 & 3.8 & 0.01 & 4.0 & 18 \\
AM & 1.5 & 0.10 & 5.5 & 6.9 & 15.8 & 0.11 & 197 & 220 \\
MAXV & 4.4 & 0.31 & 16.4 & 8.9 & 71.5 & 1.00 & 5920 & 3268 \\
STD & 0.6 & 0.04 & 4.2 & 1.1 & 10.2 & 0.11 & 413 & 185 \\
GM & 1.4 & 0.09 & 3.6 & 6.9 & 13.5 & 0.09 & 120 & 186 \\
\hline
\end{tabular}

MINV: minimum value; MAXV: maximum value; AM: mean; GM: geometric mean; STD: standard deviation.

The total concentrations for the heavy metals in these soils based on the 30 representative top soils of the study area (Table 2) were ( $\left.\mathrm{mg} \mathrm{kg}^{-1}\right)$ : ranges, $\mathrm{Cd}<$ d.1.-0.7; $\mathrm{Cr} 10.8-89$, Cu 9.5-489, Ni 5.2-48.6,

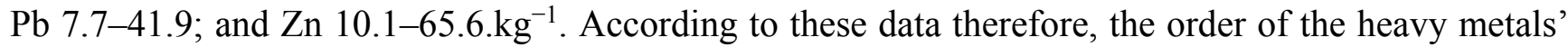
total content was $\mathrm{Cr}>\mathrm{Zn}>\mathrm{Ni}>\mathrm{Pb}>\mathrm{Cu}>>\mathrm{Cd}$. In general, in all the soils these levels are low compared with literature values for Mediterranean agricultural soils [46,47]. The ZnEqT values $\left(252 \pm 135 \mathrm{mg} \mathrm{kg}^{-1}\right)$ were also lower than Gil et al. [12] obtained in Mediterranean greenhouse soils, and the present study's heavy metal total concentrations do not surpass the RV established by Inácio et al. [24] in Portuguese soils or the GBC values of natural soils in the Mediterranean region established by Roca-Pérez et al. [25].

Table 2. Total concentrations ( $\mathrm{mg} \mathrm{kg}^{-1}$ dry soil) of trace elements in soil samples $(n=30)$ from Caia area.

\begin{tabular}{cccccccc}
\hline Statistical Parameters & Cd & Cr & Cu & Ni & Pb & Zn & Zn EqT \\
\hline MINV & $<$ d.1. & 10.8 & 5.4 & 5.2 & 7.7 & 10.1 & 63 \\
AM & 0.6 & 48.4 & 16.7 & 23.6 & 19.1 & 29.6 & 252 \\
MAXV & 0.7 & 89.0 & 45.0 & 48.6 & 41.9 & 65.6 & 506 \\
STD & 0.1 & 25.5 & 9.1 & 13.6 & 8.9 & 15.1 & 135 \\
GM & 0.6 & 41.1 & 14.6 & 19.6 & 17.1 & 25.9 & 214 \\
\hline
\end{tabular}

$<$ d.l. below detection limit; ZnEqT: Zinc equivalent of total heavy metals.

Table 3 presents the mean concentrations of available $\mathrm{Cd}, \mathrm{Cr}, \mathrm{Cu}, \mathrm{Pb}, \mathrm{Ni}$, and $\mathrm{Zn}$ in the soils, with the corresponding values of the standard deviation, range, and geometric mean.

According to these data, the order of the available content of the metals was $\mathrm{Pb}>\mathrm{Ni}>\mathrm{Cu}>\mathrm{Cr}>$ $\mathrm{Zn}>\mathrm{Cd}$. The content of the most available heavy metal in this kind of soil, $\mathrm{Pb}$, is known to be essentially anthropogenic $[5,23]$. 
Table 3. Available concentrations $\left(\mathrm{mg} \mathrm{kg}^{-1}\right.$ dry soil) of trace elements in soil samples $(n=630)$ from Caia area with associated statistical parameters.

\begin{tabular}{cccccccc}
\hline Statistical Parameters & $\mathbf{C d}$ & $\mathbf{C r}$ & $\mathbf{C u}$ & $\mathbf{N i}$ & $\mathbf{P b}$ & $\mathbf{Z n}$ & $\mathbf{Z n ~ E q B}$ \\
\hline MINV & $<$ d.1. & $<$ d.1. & $<$ d.1. & $<$ d.1. & $<$ d.1. & $<$ d.1. & 0.3 \\
AM & 0.24 & 0.85 & 1.23 & 1.95 & 3.16 & 0.64 & 19.4 \\
MAXV & 0.55 & 3.30 & 10.00 & 6.60 & 13.00 & 5.00 & 130 \\
STD & 0.23 & 0.79 & 1.15 & 1.30 & 2.33 & 0.58 & 14.5 \\
GM & 0.15 & 0.50 & 0.86 & 1.48 & 2.25 & 0.51 & 14.3 \\
\hline
\end{tabular}

$<$ d.l. below detection limit; Zn EqB: Zinc equivalent of bioavailable heavy metals.

The availability data for $\mathrm{Cr}, \mathrm{Cu}, \mathrm{Pb}$, and $\mathrm{Zn}$ are lower than or close to those reported by different workers in the literature considering the same extractant (Table 4), but the data for $\mathrm{Pb}$ are perceptibly higher than those reported by Antolin et al. [48] and Buccolieri et al. [49]. The only work that determines available $\mathrm{Cd}$ is Antolin et al. [46] and their data are lower than we found in the study area.

Table 4. Available concentration of $\mathrm{Cd}, \mathrm{Cr}, \mathrm{Cu}, \mathrm{Ni}, \mathrm{Pb}$ and $\mathrm{Zn}$, extracted with EDTA in different soils $\left(\mathrm{mg} \mathrm{kg}^{-1}\right)$.

\begin{tabular}{cccccccc}
\hline $\begin{array}{c}\text { Heavy } \\
\text { Metals }\end{array}$ & In this work & $\begin{array}{c}\text { Bucolieri } \\
\text { et al., 2010 }\end{array}$ & $\begin{array}{c}\text { Masas } \\
\text { et al., 2009 }\end{array}$ & $\begin{array}{c}\text { Gisbert } \\
\text { et al., 2006 }\end{array}$ & $\begin{array}{c}\text { Ramos } \\
\mathbf{2 0 0 6}\end{array}$ & $\begin{array}{c}\text { Antolin } \\
\text { et al., 2005 }\end{array}$ & $\begin{array}{c}\text { Walker } \\
\text { et al., 2003 }\end{array}$ \\
\hline $\mathrm{Cd}$ & $0.24 \pm 0.23$ & n.d. & n.d. & n.d. & n.d. & $0.012-0.013$ & n.d. \\
$\mathrm{Cr}$ & $0.85 \pm 0.79$ & n.d. & $1.5 \pm 0.5$ & n.d. & n.d. & n.d. & n.d. \\
$\mathrm{Cu}$ & $1.23 \pm 1.15$ & $5.40 \pm 5.67$ & $2.5 \pm 1.2$ & $0.9-8.8$ & $15.3 \pm 4.3$ & $1.64-1.19$ & 11.3 \\
$\mathrm{Ni}$ & $1.95 \pm 1.30$ & $0.41 \pm 0.32$ & $1.3 \pm 0.9$ & n.d & n.d. & n.d & n.d. \\
$\mathrm{Pb}$ & $3.16 \pm 2.33$ & $2.09 \pm 1.92$ & $5.8 \pm 3.2$ & $22.1-179$ & n.d. & $1.34-1.75$ & $28.2-32.5$ \\
$\mathrm{Zn}$ & $0.64 \pm 0.58$ & $3.67 \pm 3.27$ & $7.8 \pm 9.7$ & $10.5-7.7$ & $2.2 \pm 1.2$ & $0.77-2.41$ & $15.2-14.4$ \\
\hline
\end{tabular}

MINV-MAXV; $\mathrm{AM} \pm \mathrm{STD}$; n.d. not determined; Adapted from [42].

Although the levels of available heavy metals vary greatly among different Mediterranean soils, the order of their concentrations in the present study are similar to those found by other workers, implying that the processes operating are similar. The levels of $\mathrm{ZnEqB}$ found are lower than those reported by Ramos-Miras et al. [42], in greenhouse soils (44.6 $\left.\pm 43.5 \mathrm{mg} \mathrm{kg}^{-1}\right)$, although they use other extracting agent.

This is indicative of the present soils being free of relevant contamination or large scale mobilization of the heavy metals analyzed as might have been caused by farming activities, despite the large amounts of fertilizers (available phosphorous and potassium) detected in them.

\subsection{Baseline Concentrations}

Soils constitute a complicated and heterogeneous system [50], so that simple monitoring of their heavy metal concentrations is insufficient guarantee of their environmental quality. Their trace element contents vary widely, so that it is inappropriate to use universal background concentrations as a criterion since the native concentrations of metals in a specific soil may exceed any given listed ranges. It is therefore important to determine the values of the GBC and RV concentrations locally $[8,18,42,51,52]$. To estimate the GBC values, the "standard threshold method" was applied [43]. The Q-Q plots are 
shown in Figure 2. Low values deviate from linearity because they were beneath the detection limit, and were hence assigned the detection limit value as proposed by Tack et al. [41]. The threshold was chosen as the point at which the slope of the Q-Q plot changes. Values beneath the threshold point denote the $\mathrm{GBC}(0.91,2.52,6.33,7,32,4.60,2.53$ threshold point of $\mathrm{Cd}, \mathrm{Cr}, \mathrm{Cu}, \mathrm{Ni}, \mathrm{Pb}$ and $\mathrm{Zn}$, respectively). The resulting $\mathrm{GBC}$ ranges were (in $\mathrm{mg} \mathrm{kg}^{-1}$ ): 0.04 to $0.90,0.70$ to $2.50,0.10$ to 6.30 , 0.30 to $7.30,0.29$ to 4.50 , and 0.18 to 2.50 for $\mathrm{Cd}, \mathrm{Cr}, \mathrm{Cu}, \mathrm{Ni}, \mathrm{Pb}$, and $\mathrm{Zn}$, respectively. The $\mathrm{BL}$ estimated from non-contaminated soils were (in $\mathrm{mg} \mathrm{kg}^{-1}$ ): $0.23,0.72,1.22,2.00,1.96$, and 0.57 for $\mathrm{Cd}$, $\mathrm{Cr}, \mathrm{Cu}, \mathrm{Ni}, \mathrm{Pb}$ and $\mathrm{Zn}$, respectively. The method of threshold points allows the differentiation of homogeneous populations using statistical criteria, assuming that populations with higher contents of heavy metals are subject to contamination processes.

Figure 2. Normal probability plot of bioavailable $\mathrm{Cd}, \mathrm{Cr}, \mathrm{Cu}, \mathrm{Pb}, \mathrm{Ni}$ and $\mathrm{Zn}$ contents as logconcentration.
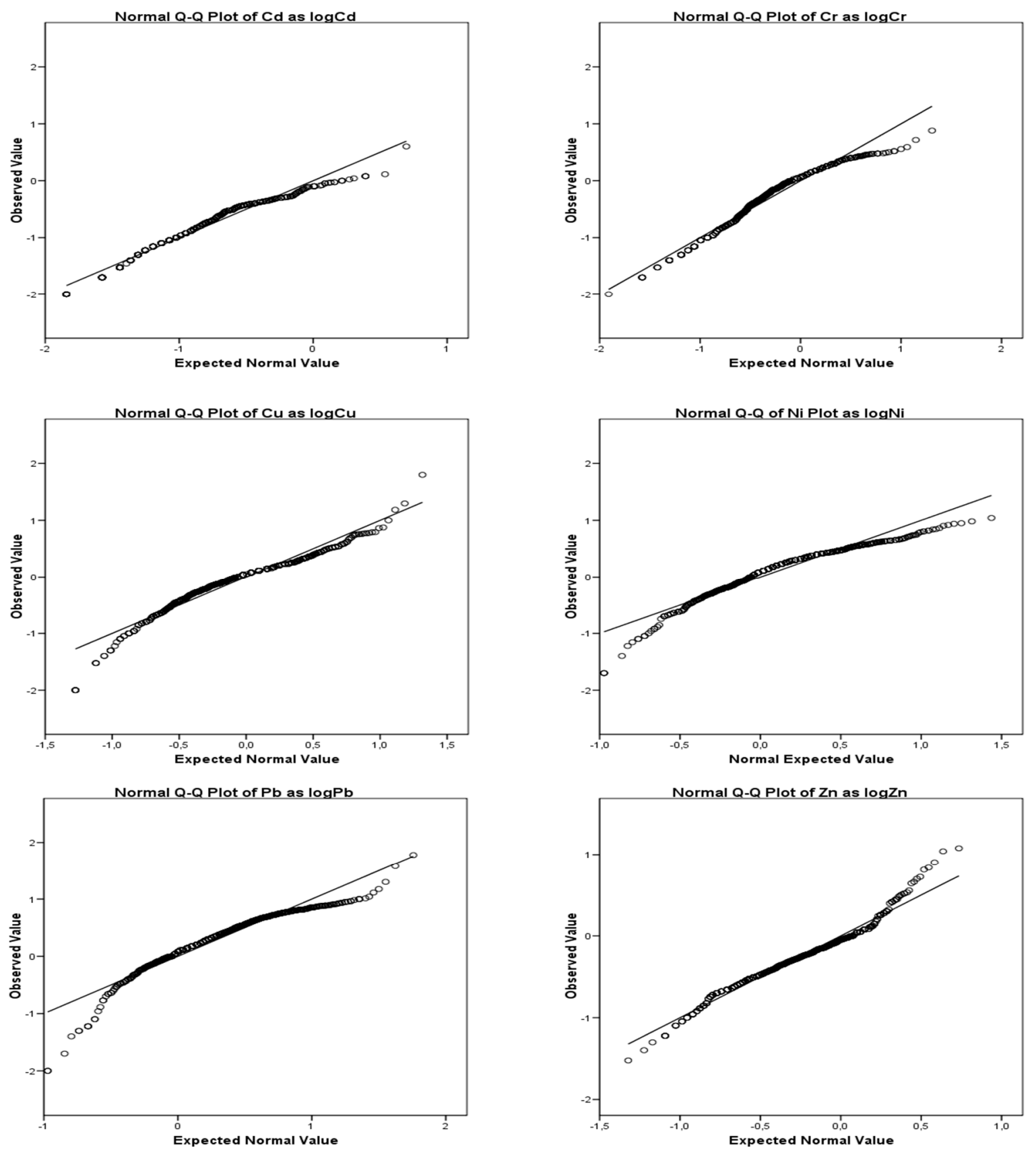
There are only two literature studies on the GBC of available heavy metals in soils-Tarvainen and Kallio [32] in natural soils in Finland, and Ramos-Miras et al. [42] in agricultural soils. They both used EDTA for extraction, however, so that it is difficult to compare their results with the present findings, even more so given that they did not analyze the same heavy metals. Nevertheless, the present results lie within the limits proposed by those authors.

The upper limit of the GBC could be used as the RV against which to assess soil contamination [31] find that this method is far more effective than others that have been put forward in the specialized literature. Using therefore the upper GBC values as the RVs of the available heavy metals (Cd 0.9; $\mathrm{Cr}$ 2.5; $\mathrm{Cu}$ 6.3; $\mathrm{Ni}$ 7.9; $\mathrm{Pb} 4.5$; and $\mathrm{Zn} \mathrm{2.50;} \mathrm{all} \mathrm{in} \mathrm{mg} \mathrm{kg}^{-1}$ ) with which to determine whether or not a soil is contaminated, we found that $2 \%$ for $\mathrm{Cd}, 6 \%$ for $\mathrm{Cr}, 1 \%$ for $\mathrm{Cu}, 4.5 \%$ for $\mathrm{Pb}, 5 \%$ for $\mathrm{Ni}$, and $4 \%$ for $\mathrm{Zn}$ of the samples were slightly contaminated. In particular, only $6 \%$ of the sample soils had a higher available content of heavy metals than the RV limit (due mainly to $\mathrm{Cr}, \mathrm{Cu}, \mathrm{Ni}$, and $\mathrm{Pb}$ ). The difference of $\mathrm{BL}$ and $\mathrm{GBC}$ could be because of diffuse pollution. In sum, these results point to a minimal extension of soil contamination by available heavy metals. Using the $90 \%$ percentile value as reference to determine where a soil could be contaminated like Tack et al. [41] (Table 5). All of the heavy metals values for $90 \%$ percentile were lower than the RV proposed for these soils in this work, except for $\mathrm{Pb}$, who value of $90 \%$ is higher than $\mathrm{RV}$. This fact confirms that the contamination for available heavy metals was minimal except for $\mathrm{Pb}$, who is one of the most mobile [42,53].

Table 5. Estimated of baseline concentrations of Available heavy metals ( $\mathrm{mg} \mathrm{kg}^{-1}$ dry soil) based on percentile values of the data considered to be baseline values.

\begin{tabular}{ccccccc}
\hline Percentile & $\mathbf{C d}$ & $\mathbf{C r}$ & $\mathbf{C u}$ & $\mathbf{P b}$ & $\mathbf{N i}$ & $\mathbf{Z n}$ \\
\hline $5 \%$ & 0.01 & 0.05 & 0.14 & 0.24 & 0.35 & 0.14 \\
$25 \%$ & 0.07 & 0.18 & 0.53 & 1.30 & 0.83 & 0.32 \\
$50 \%$ & 0.16 & 0.55 & 1.00 & 2.50 & 1.70 & 0.50 \\
$75 \%$ & 0.37 & 1.10 & 1.60 & 4.60 & 2.70 & 0.72 \\
$90 \%$ & 0.50 & 1.70 & 2.37 & 6.10 & 3.56 & 1.00 \\
$95 \%$ & 0.70 & 2.00 & 3.30 & 6.80 & 3.94 & 1.20 \\
$99 \%$ & 0.92 & 2.30 & 5.70 & 7.70 & 4.40 & 1.90 \\
\hline
\end{tabular}

\subsection{Correlation Analysis}

A soil's physicochemical parameters can greatly influence metal assimilation by plant roots, affecting both root growth and the mobility of the contaminants. Understanding the relationship between the elements present and those parameters could help clarify the behavior of the elements in the soil. We therefore analyzed the potential correlations between the available heavy metal concentrations and soil $\mathrm{pH}, \mathrm{SOM}$, soil carbonates, $\mathrm{P}_{2} \mathrm{O}_{5}, \mathrm{~K}_{2} \mathrm{O}, \mathrm{EC} 25$, and $\mathrm{ZnEqB}$ for the 630 soil samples, after confirm the data normality. The results are presented in Table 6. Most of the correlations were statistically significant ( $\alpha=0.01$ and $\alpha=0.05$ ). The correlations of especial interest were SOM-available heavy metals, $\mathrm{pH}$-available heavy metals, available phosphorous and potassium-available heavy metals, and those between the available heavy metal themselves.

The SOM values were positively correlated with the available heavy metal contents, reflecting the affinity of these metals for the organic matter in the soil [54-57]. All the available heavy metal 
concentrations were positively correlated with $\mathrm{pH}$. This last result was unexpected because most of the literature consulted describes an increase in $\mathrm{pH}$ as leading to a decrease in the available heavy metal content $[58,59]$. This might be because increased $\mathrm{pH}$ 's could thus favor the release of these metals by mobilizing the soil components in which they are retained. Although heavy metals are more weakly bound to soil particles in contaminated soils than in purely lithogenic ones, and are hence more readily mobilized [60-62].

Table 6. Spearman Correlation coefficients of Available heavy metal concentrations with soil properties in Caia agricultural soils $(n=630)$.

\begin{tabular}{|c|c|c|c|c|c|c|c|c|c|c|c|c|}
\hline Parameters & pH & SOM & $\mathbf{P}_{2} \mathbf{O}_{5}$ & $\mathrm{~K}_{2} \mathrm{O}$ & Soil Carbonates & $\mathrm{EC}_{25}$ & Cd & $\mathrm{Cr}$ & $\mathbf{C u}$ & $\mathbf{N i}$ & $\mathbf{P b}$ & $\mathbf{Z n}$ \\
\hline $\mathrm{pH}$ & 1 & & & & & & & & & & & \\
\hline SOM & $0.357\left(^{\#}\right)$ & 1 & & & & & & & & & & \\
\hline $\mathrm{P}_{2} \mathrm{O}_{5}$ & $0.391\left(^{\#}\right)$ & $0.178(\#)$ & 1 & & & & & & & & & \\
\hline $\mathrm{K}_{2} \mathrm{O}$ & $0.429\left({ }^{\#)}\right.$ & $0.346(\#)$ & $0.428\left(^{\#}\right)$ & 1 & & & & & & & & \\
\hline $\begin{array}{c}\text { Soil } \\
\text { Carbonates }\end{array}$ & $0.510\left(^{\#}\right)$ & $0.313\left({ }^{\#)}\right.$ & $-0.281(\#)$ & n.s. & 1 & & & & & & & \\
\hline $\mathrm{EC}_{25}$ & $0.283\left({ }^{*}\right)$ & $0.208\left({ }^{*}\right)$ & $0.257\left({ }^{\#}\right)$ & $0.344\left({ }^{*}\right)$ & & 1 & & & & & & \\
\hline $\mathrm{Cd}$ & $0.507\left(^{*}\right)$ & $0.294\left({ }^{*}\right)$ & $0.183\left({ }^{\#}\right)$ & $0.194\left({ }^{*}\right)$ & $0.587(\#)$ & $0.150\left(^{*}\right)$ & 1 & & & & & \\
\hline $\mathrm{Cr}$ & $0.480\left(^{\#}\right)$ & $0.251\left({ }^{\#}\right)$ & $0.143\left({ }^{\#}\right)$ & $0.265(\#)$ & $0.486\left({ }^{\#}\right)$ & $0.132\left(^{*}\right)$ & $0.536(\#)$ & 1 & & & & \\
\hline $\mathrm{Cu}$ & $0.583\left({ }^{\#}\right)$ & $0.369(\#)$ & $0.264\left({ }^{\#}\right)$ & $0.330\left(^{\#}\right)$ & n.s. & $0.121\left({ }^{*}\right)$ & $0.182(\#)$ & $0.224\left({ }^{\#}\right)$ & 1 & & & \\
\hline $\mathrm{Ni}$ & $0.554\left({ }^{\#}\right)$ & $0.289\left({ }^{\#}\right)$ & $0.190\left(^{\#}\right)$ & $0.247(\#)$ & $0.299\left(^{\#)}\right.$ & n.s. & $0.393\left({ }^{\#}\right)$ & $0.413\left({ }^{\#)}\right.$ & $0.535\left(^{\#}\right)$ & 1 & & \\
\hline $\mathrm{Pb}$ & $0.616\left({ }^{\#}\right)$ & $0.359\left({ }^{\#}\right)$ & $0.311\left(^{\#}\right)$ & $0.409\left({ }^{\#}\right)$ & $0.515(\#)$ & $0.217\left({ }^{*}\right)$ & $0.544\left({ }^{\#}\right)$ & $0.443\left({ }^{*}\right)$ & $0.416\left(^{\#}\right)$ & $0.398\left({ }^{\#}\right)$ & 1 & \\
\hline $\mathrm{Zn}$ & $0.354\left(^{*}\right)$ & $0.415\left(^{*}\right)$ & $0.297\left({ }^{\#}\right)$ & $0.245\left(^{*}\right)$ & $0.134(*)$ & $0.182\left({ }^{*}\right)$ & $0.307\left({ }^{\#}\right)$ & $0.204\left({ }^{*}\right)$ & $0.340\left(^{(*)}\right.$ & $0.213\left(^{*}\right)$ & $0.296\left({ }^{\#}\right)$ & 1 \\
\hline Zn EqB & $0.610\left(^{\#}\right)$ & $0.351\left(^{\#}\right)$ & $0.232\left(^{\#}\right)$ & $0.297(\#)$ & $0.281\left({ }^{\#}\right)$ & n.s. & $0.407\left({ }^{\#}\right)$ & $0.412\left({ }^{\#}\right)$ & $0.663\left(^{\#}\right)$ & $0.971\left(^{\#}\right)$ & $0.451\left({ }^{\#}\right)$ & $0.294\left(^{\#}\right)$ \\
\hline
\end{tabular}

\# Significantly at levels of $\alpha$ 0:05 and 0.01, respectively; $N=630$; n.s. not significant.

The $\mathrm{Cd}, \mathrm{Cr}, \mathrm{Pb}$, and $\mathrm{Ni}$ levels were correlated with soil carbonates, suggesting their presence in these soils in a form linked to carbonates $[58,63]$. The available phosphorus and potassium content was positively correlated with the available heavy metal contents, possibly reflecting the presence of heavy metal contaminants in fertilizers $[44,45,64]$. The available phosphorus and potassium content was also positively correlated with the $\mathrm{ZnEqB}$ contamination index, which would be consistent with the aforementioned result. There were also significant correlations between the available heavy metals and EC25. Any increase in ionic strength caused by salts in a soil promotes the release of heavy metals, especially $\mathrm{Cd}$ and $\mathrm{Pb}$, due to competition for sorption sites by cations and metal-complexation anions $[47,65,66]$.

Finally, there were significant positive correlations between the heavy metals themselves. This is suggestive of a similar, if not identical, origin of the heavy metals, and indicating that anthropic activities could enhancing the mobility of these elements $[18,42]$. There was further support for this interpretation in the strong positive correlations between the $\mathrm{ZnEqB}$ contamination index and the available $\mathrm{Cd}, \mathrm{Cr}, \mathrm{Cu}, \mathrm{Pb}, \mathrm{Ni}$, and $\mathrm{Zn}$ contents. 


\section{Conclusions}

The concentrations of total and available heavy metals in these agricultural soils, which are typical of the Mediterranean region, were generally lower than or close to those reported in the literature for other agricultural areas. The GBCs of the available heavy metals were: 0.04 to $0.90 \mathrm{mg} \mathrm{kg}^{-1}, 0.70$ to $2.50 \mathrm{mg} \mathrm{kg}-1,0.10$ to $6.30 \mathrm{mg} \mathrm{kg}-1,0.30$ to $7.90 \mathrm{mg} \mathrm{kg}^{-1}, 0.29$ to $4.50 \mathrm{mg} \mathrm{kg}^{-1}$, and 0.18 to $2.50 \mathrm{mg} \mathrm{kg}^{-1}$, for $\mathrm{Cd}, \mathrm{Cr}, \mathrm{Cu}, \mathrm{Ni}, \mathrm{Pb}$, and $\mathrm{Zn}$, respectively. The threshold method is a good way to establish GBC values in an initially homogeneous population of soil. Only a small percentage of the 630 soils sampled had high available levels of heavy metals, so that there is no evidence for any extensive heavy metal contamination of these soils. All the available heavy metal concentrations were strongly correlated with $\mathrm{pH}$ and SOM. Even though the concentrations lay within normal ranges for most of the soil samples, the multivariate analysis indicated that the available $\mathrm{Cd}, \mathrm{Cr}, \mathrm{Pb}, \mathrm{Ni}, \mathrm{Cu}$, and $\mathrm{Zn}$ contents were essentially driven by anthropic activities. This indication was supported by their strong correlations with the $\mathrm{ZnEqB}$ index.

Given the potential risk to human health represented by available heavy metals, especial effort is called for to determine both the locations of contaminated soils and the sources of their contamination in order to be able to halt the contamination process and avoid larger areas being affected. We must emphasize that the present results are preliminary, and the findings will be more extensively studied in future work.

\section{Acknowledgments}

The authors would like to acknowledge financial support given by the Centre for Spatial and Organizational Dynamics (CIEO) and from the Foundation for Science and Technology (FCT).

\section{Author Contributions}

José Rato Nunes, António López-Piñeiro and José Coelho design the research and performed the chemical analysis, José Ramos-Miras, Luís Loures, Carlos Gil, and Ana Loures wrote the paper. José Rato Nunes made the final revision of the paper and answer to the reviews questions.

\section{Conflicts of Interest}

The authors declare no conflict of interest.

\section{References}

1. Ramos, M. Metals in vineyard soils of the Penedès area (NE Spain) after compost application. J. Environ. Manag. 2006, 78, 209-215.

2. Kosmas, C.; Danalatos, N.; López-Bermúdez, F.; Romero-Díaz, M. The effect of land use on soil erosion and land degradation under Mediterranean conditions. In Mediterranean Desertification: A Mosaic of Processes and Responses; Geeson, N., Brandt, C., Thornes, J., Eds.; Wiley: Chichester, UK, 2002; pp. 57-70. 
3. Zalidis, G.; Stamatiadis, S.; Takavakoglou, V.; Eskridge, K.; Misopolinos, N. Impacts of agricultural practices on soil and water quality in The Mediterraneam region and proposed assessment methodology. Agric. Ecosyst. Environ. 2002, 88, 137-146.

4. Romic, M.; Romic, D. Heavy metal distribution in agricultural topsoils in urban area. Environ. Geol. 2003, 43, 795-805.

5. Kelepertzis, E. Accumulation of heavy metals in agricultural soils of Mediterranean: Insights from Argolina Basin, Paloponnese, Grece. Geoderma 2014, 221-222, 82-90.

6. Borrego, C. Water, air and soil pollution problems in Portugal. Sci. Total Environ. 1993, 129, 55-70.

7. Loures, L.; Panagopoulos, T. From derelict industrial areas towards multifunctional landscapes and urban renaissance. WSEAS Trans. Environ. Dev. 2007, 3, 181-188.

8. Loures, L.; Santos, R.; Panagopoulos, T. Urban parks and sustainable city planning-The case of Portimão, Portugal. WSEAS Trans. Environ. Dev. 2007, 3, 171-180.

9. Loures, L.; Heuer, T.; Horta, D.; Silva, S.; Santos, R. Multifunctional clusters in Post-industrial Landscapes: Rising from what's left. WSEAS Trans. Environ. Dev. 2008, 4, 619-628.

10. De Tammerman, L.; Vanongeval, L.; Boon, W.; Hoenig, M. Heavy metal content of arable soils in Northern Beliguim. Water Air Soil Pollut. 2003, 148, 61-76.

11. Rodríguez-Martín, J.; López-Arias, M.; Grau-Corbí, J. Heavy metals contents in agricultural topsoils in the Ebro basin (Spain). Application of the multivariate geoestatistical methods to study spatial variations. Environ. Pollut. 2006, 144, 1001-1012.

12. Gil, C.; Ramos-Miras, J.; Roca-Perez, L.; Boluda, R. Determination and assessment of mercury content in calcareous soils. Chemosphere 2010, 78, 409-415.

13. Romaguera, F.; Boluda, R.; Fornes, F.; Abad, M. Comparison of three sequential extraction procedures for trace element partitioning in three contaminated Mediterranean soils. Environ. Geochem. Health 2008, 30, 171-175.

14. Adriano, D. Trace Elements in Terrestrial Environments: Biochemistry, Bioavailability and Risks of Metals; Springer-Verlag: New York, NY, USA, 2001.

15. Abollino, O.; Aceto, M.; Malandrino, M.; Mentasti, E.; Sarzanini, C.; Petrella, F. Heavy metals in agricultural soils from Piedmont, Italy. Distribution, speciation and chemometric data treatment. Chemosphere 2002, 49, 545-557.

16. Vig, K.; Megharaj, M.; Sethunathan, N.; Naidu, R. Bioavailability and toxicity of cadmium to microorganisms and their activities in soil: A review. Adv. Environ. Res. 2003, 8, 121-135.

17. Andreu, V.; Boluda, R. Application of contamination indexes on different farming soils. Bull. Environ. Contam. Toxicol. 1995, 54, 228-236.

18. Gil, C.; Boluda, R.; Ramos, J. Determination and evaluation of cadmium lead and nickel in greenhouse soils of Almería (Spain). Chemosphere 2004, 55, 1027-1034.

19. Martínez-Alcalá, I.; Clemente, R.; Bernal, M. Metal Availability and chemical properties in the rhizosphere of Lupinus albus L. growing in a high-metal calcareous soil. Water Air Soil Pollut. 2009, 201, 283-293.

20. Meyer, J. The utility of the terms "bioavailability" and "bioavailable fraction" for metals. Mar. Environ. Res. 2002, 53, 417-423.

21. Peijnenburg, W.; Jager, T. Monitoring approaches to assess bioaccessibility and bioavailability of metals: Matrix issues. Ecotoxicol. Environ. Saf. 2003, 56, 63-77. 
22. Cao, A.; Cappai, G.; Carucci, A.; Lai, T. Heavy metal bioavailability and chelate mobilization efficiency in an assisted phytoextraction process. Environ. Geochem. Health 2008, 30, 115-119.

23. De Vivo, B.; Somma, R.; Ayuso, R.; Calderoni, G.; Lima, A.; Pagliuca, S.; Sava, A. Pb isotopes and toxic metals in floodplain and stream sediments from the Volturno river basin, Italy. Environ. Geol. 2001, 41, 101-112

24. Inácio, M.; Pereira, V.; Pinto, M. The Soil Geochemical Atlas of Portugal: Overview and applications. J. Geochem. Explor. 2008, 98, 22-33.

25. Albanese, S.; de Vivo, B.; Lima, A.; Cicchella, D.; Civitillo, D.; Cosenza, A. Geochemical baselines and risk assessment of the Bagnoli brownfield site coastal sea sediments (Naples, Italy). J. Geochem. Explor. 2010, 105, 19-33.

26. Roca-Pérez, L.; Gil, C.; Cervera, M.; Gonzálvez, A.; Ramos-Miras, J.; Ponsa, V.; Bech, J.; Boluda, R. Selenium and heavy metals content in some Mediterranean soils. J. Geochem. Explor. 2010, 107, 110-116.

27. Albanese, S.; de Vito, B.; Lima, A.; Cicchella, D. Geochemical background and baseline values of toxic elements in stream sediments of Campania region (Italy). J. Geochem. Explor. 2007, 93, 21-34.

28. Guillén, M.; Delgado, J.; Albanese, S.; Nieto, J.; Lima, A.; de Vivo, B. Environmental geochemical mapping of Huelva municipality soils (SW Spain) as a tool to determine background and baseline values. J. Geochem. Explor. 2011, 109, 59-69.

29. Galán, E.; Fernández-Caliani, J.; González, I.; Aparicio, P.; Romero, A. Influence of geological setting on geochemical baselines of trace elements in soils. Application to soils of South-West Spain. J. Geochem. Explor. 2008, 98, 89-106.

30. Tume, P.; Bech, J.; Tume, L.; Bech, J.; Reverter, F.; Longan, L.; Cendoya, P. Concentrations and distributions of $\mathrm{Ba}, \mathrm{Cr}, \mathrm{Sr}, \mathrm{V}, \mathrm{Al}$, and $\mathrm{Fe}$ in Torrelles soil profiles (Catalonia, Spain). J. Geochem. Explor. 2008, 96, 94-105.

31. Díez, M.; Simón, M.; Martín, F.; Dorronsoro, C.; García, I.; van Gestel, C. Ambient trace element background concentrations in soils and their use in risk assessment. Sci. Total Environ. 2009, 407, $4622-4632$.

32. Tarvainen, T.; Kallio, E. Baselines of certain bioavailable and total heavy metal concentrations in Finland. Appl. Geochem. 2002, 17, 975-980.

33. Baldantoni, D.; Leone, A.; Lovieno, P.; Morra, L.; Zaccardelli, M.; Alfani, A. Total and available soil trace element concentrations in two Mediterranean agricultural systems treated with municipal waste compost or conventional mineral fertilizers. Chemosphere 2010, 80, 1006-1013.

34. Nunes, J. Los Suelos del Perímetro Regable del Caia (Portugal): Tipos, Fertilidade, e Impacto del Riego en sus Propriedades Químicas. Ph.D. Dissertation, Faculdad de Ciencias, Universidad de Extremadura, Badajoz, Spain, 2003.

35. Roca-Pérez, L.; Pérez-Bermúdez, P.; Boluda, R. Soil characteristics, mineral nutrients, biomass, and cardenolide production in Digitalis obscura wild populations. J. Plant Nutr. 2002, 25, 2015-2026.

36. United States Department of Agriculture. Soil Survey Laboratory Methods Manual; United States Department of Agriculture: Lincoln, NE, USA, 2004.

37. Lindsay, W.L.; Norvell, W.A. Development of a DTPA soil test for zinc, iron, manganese and cupper. Soil Sci. Soc. Am. J. 1978, 42, 421-428. 
38. Hooda, P.; Alloway, B. The plant availability and DTPA extractability of trace metals in sludge-amended soils. Sci. Total Environ. 1994, 149, 39-51.

39. Soriano-Disla, J.; Gómez, I.; Guerrero, C.; Jordan, M.; Navarro-Pedreño, J. Soil factors related to heavy metal bioavailability after sewage sludge application. Fresenius Environ. Bull. 2008, 17, $1839-1845$.

40. Hao, X.; Zhou, D.; Huang, D.; Cang, L.; Zhang, L.; Wang, H. Heavy Metal Transfer from Soil to Vegetable in Southern Jiangsu Province. China Pedosphere 2009, 19, 305-311.

41. Tack, F.; Vanhaesebroeck, T.; Verloo, M.; van Rompaey, K.; van Ranst, E. Mercury baseline levels in Flemish soils (Belgium). Environ. Pollut. 2005, 134, 173-179.

42. Ramos-Miras, J.; Roca-Perez, L.; Guzmán-Palomino, M.; Boluda, R.; Gil, C. Background levels and baseline values of available heavy metals in Mediterranean greenhouse soils (Spain). J. Geochem. Explor. 2011, 110, 186-192.

43. Fleischhauer, H.; Korte, N. Formulation of cleanup standards for trace elements with probability plots. Environ. Manag. 1990, 14, 95-105.

44. Nziguheba, G.; Smolders, E. Inputs of trace elements in agricultural soils via phosphate fertilizers in European countries. Sci. Total Environ. 2008, 390, 53-57.

45. Cheraghi, M.; Lorestani, B.; Merrikhpour, H. Investigation of the effects of phosphate fertilizer application on the heavy metal content in agricultural soils with different cultivation patterns. Biol. Trace Element Res. 2012, 145, 87-92.

46. Caridad-Cancela, R.; Vidal-Vázquez, E.; Vieira, S.; Abreu, C.; Paz-González, A. Assesing the spatial uncertainity of mapping trace elements in cultivated fields. Commun. Soil Sci. Plant Anal. 2005, 36, 253-274.

47. Peris, M.; Recatalá, L.; Micó, C.; Sánchez, R.; Sánchez, J. Heavy metal contents in horticultural crops of a representative area of the European Mediterranean region. Sci. Total Environ. 2007, 378, 42-48.

48. Antolín, M.; Pascual, I.; García, C.; Polo, A.; Sánchez-Díaz, M. Growth, yield and solute content of barley in soils treated with sewage sludge under semiarid Mediterranean conditions. Field Crops Res. 2005, 94, 224-237.

49. Buccolieri, A.; Buccolieri, G.; Dell'Atti, A.; Strisciullo, G.; Gagliano-Candela, R. Monitoring of total and bioavailable heavy metals concentration in agricultural soils. Environ. Monit. Assess. 2010, 168, 547-560.

50. Chen, H.; Zheng, C.; Tu, C.; Zhou, D. Studies on loading capacity of agricultural soils for heavy metals and its applications in China. Appl. Geochem. 2001, 16, 1397-1403.

51. Matschullat, J.; Ottenstein, R.; Reimann, C. Geochemical background-Can we calculate it? Environ. Geol. 2000, 39, 990-1000.

52. Horckmans, L.; Swennen, R.; Deckers, J.; Maquil, R. Local background concentrations of trace elements in soils: A case study in the Grand Duchy of Luxembourg. Catena 2005, 59, 279-304.

53. Massas, I.; Ehaliotis, C.; Kalivas, D.; Panagopoulou, G. Concentrations and availability indicators of soil heavy metals; the case of children's playgrounds in the city of Athens (Greece). Water Air Soil Pollut. 2010, 212, 51-63. 
54. Römkens, P.; Guo, H.; Chu, L.; Liu, T.; Chiang, C.; Koopmans, G. Characterization of soil heavy metal pools in paddy fields in Taiwan: Chemical extraction and solid-solution partitioning. J. Soil Sediments 2009, 9, 216-228.

55. Vega, F.; Covelo, E.; Andrade, M.; Marcet, P. Relationships between heavy metals content and soil properties in minesoils. Anal. Chim. Acta 2004, 524, 141-150.

56. Businelli, D.; Massaccesi, L.; Said-Pullicino, D.; Gigliotti, G. Long-term distribution, mobility and plant availability of compost-derived heavy metals in a landfill covering soil. Sci. Total Environ. 2009, 407, 1426-1435.

57. Tarvainen, T.; Jarva, J.; Kahelin, H. Geochemical baselines in relation to analytical methods in the Itä-Uusimaa and Pirkanmaa regions, Finland. Geochem. Explor. Environ. Anal. 2009, 9, 81-92.

58. Alloway, B. Heavy Metals in Soils; Blackie and Son Ltd.: London, UK, 1995.

59. Acosta, J.; Faz, A.; Martínez-Martínez, S. Identification of heavy metal sources by multivariable analysis in a typical Mediterranean city (SE Spain). Environ. Monit. Assess. 2010, 169, 519-530.

60. Lim, T.; Tay, J.; Teh, C. Contaminant time effect on lead and cadmium fraction in a tropical coastal clay. J. Environ. Q. 2002, 31, 806-812.

61. Lu, A.; Zhang, S.; Shan, X. Time effect of the fractionation of heavy metals in soils. Geoderma 2005, 125, 225-234.

62. Massas, I.; Ehaliotis, C.; Gerontidis, S.; Sarris, E. Elevated heavy metal concentrations in top soils of an Aegean island town (Greece): Total and available forms, origin and distribution. Environ. Monit. Assess. 2009, 151, 105-116.

63. Gupta, U.; Gupta, S. Trace element toxicity relationships to crop production and livestock and human health: Implications for management. Commun. Soil Sci. Plant Anal. 1998, 29, 1491-1522.

64. Gimeno-García, E.; Andreu, V.; Boluda, R. Heavy metals incidence in the application of inorganic fertilizers and pesticides to rice farming soils. Environ. Pollut. 1996, 92, 19-25.

65. Hatje, V.; Payne, T.; Hill, D.; McOrist, G.; Birch, G.; Szymczak, R. Kinetics of trace element uptake and release by particles in estuarine waters: Effects of $\mathrm{pH}$, salinity, and particle loading. Environ. Int. 2003, 29, 619-629.

66. Acosta, J.; Jansen, B.; Kalbitz, K.; Faz, A.; Martínez-Martínez, S. Salinity increases mobility of heavy metals in soils. Chemosphere 2011, 85, 1318-1324.

(C) 2014 by the authors; licensee MDPI, Basel, Switzerland. This article is an open access article distributed under the terms and conditions of the Creative Commons Attribution license (http://creativecommons.org/licenses/by/4.0/). 